\title{
A comparative approach to study inhibition of grazing and lipid composition of a toxic and non-toxic clone of Chrysochromulina polylepis (Prymnesiophyceae)
}

\author{
Uwe John*, Urban Tillmann, Linda K. Medlin \\ Alfred Wegener-Institute for polar and marine research, Am Handelshafen 12, D-27570 Bremerhaven, Germany \\ Received 26 October 2001; received in revised form 11 January 2002; accepted 5 February 2002
}

\begin{abstract}
Since the massive bloom in 1988 in the North Sea, the prymnesiophyte flagellate Chrysochromulina polylepis Manton et Parke has been known for its ichtyotoxicity. Laboratory experiments using two different clones of $C$. polylepis were conducted in a comparative approach. Both clones were nearly similar in size and shape, but differed in their toxicity, as demonstrated by the Artemia bioassay. In order to study the effects of toxic $C$. polylepis on protozooplankton grazers, grazing experiments were performed with the heterotrophic dinoflagellate Oxyrrhis marina Dujardin as grazer. A first experiment was carried out in order to follow batch culture growth and initial grazing of $O$. marina when fed toxic or non-toxic clones of $C$. polylepis. Ingestion of the toxic clone was $27 \%$ of ingestion when fed with the non-toxic clone. When $O$. marina was fed with the toxic clone, vacuoles within O. marina contained fewer food particles per cell and the cells attained slower division rate (58\% of the division rate estimated for the non-toxic clone). A second experiment was conducted to determine the grazing and growth response of $O$. marina as a function of algal food concentration. Profound differences in ingestion, clearance, division and gross growth efficiency of $O$. marina when fed the two clones of $C$. polylepis again were apparent. However, even at algal concentrations of $400 \times 10^{3} \mathrm{ml}^{-1}$, O. marina is not killed by the presence or by the ingestion of toxic C. polylepis, indicating that the toxin deters grazers. In addition to grazing experiments, lipid classes and fatty acids of both algal clones were analysed and compared in order to follow the hypothesis that toxicity of $C$. polylepis is caused by liposaccharides, lipids, or fatty acids. However, the chemical composition with respect to lipid classes and fatty acids of both clones were quite similar, making an involvement of these substances in the toxicity towards Artemia and O. marina unlikely. @ 2002 Elsevier Science B.V. All rights reserved.
\end{abstract}

Keywords: Chrysochromulina polylepis; Grazing inhibition; Lipid composition; Oxyrrhis marina; Toxic algae

\section{Introduction}

The prymnesiophyte Chrysochromulina polylepis was described from the North Sea in the mid 1950s (Manton and Parke, 1962). Although this species previously was believed to be non-toxic to fish

\footnotetext{
* Corresponding author. Tel.: +49-471-4831-1841; fax: +49-471-4831-1425.

E-mail address: ujohn@awi-bremerhaven.de (U. John).
}

(Manton and Parke, 1962), an extraordinary bloom of $C$. polylepis in the Kattegat/Skagerrak area and off the Norwegian coast in 1988 caused extensive fish kills. Since then, a number of blooms of different Chrysochromulina species have been reported, some of which have caused fish mortality (reviewed by Edvardsen and Paasche, 1998). The 1988 bloom extended over an area of approximately $75,000 \mathrm{~km}^{2}$ (Granéli et al., 1993) and was characterised by pronounced toxic effects to various organisms, which, 
along with farm fish and wild fish populations, included mussels, echinoderms, polychaets, ascidians, cnidarians, sponges, red and brown algae (Rosenberg et al., 1988) as well as bacteria, protozoans, copepods (Nielsen et al., 1990) and other microalgae (Dahl et al., 1989, Johnsen and Lomsland, 1990). The factors and mechanism that led to the bloom have been intensively reviewed and discussed (Maestrini and Granéli, 1991, Gjøsæter et al., 2000). In addition to unusual physical and chemical conditions in 1988, adverse effects of $C$. polylepis to planktonic grazers may have played an important role in the development of the almost monospecific bloom, as reduced or inhibited grazing is generally believed to be an important factor in harmful bloom dynamics (Smayda, 1997).

Generally, toxins produced by $C$. polylepis are non-selective, interfere mainly with membrane function and thus may affect organisms ranging from protozoa to fish. Their chemical structures are not fully elucidated yet, although Yasumoto et al. (1990) described them as lipids and/or fatty acids. Toxicity of Chrysochromulina was demonstrated to be highly variable even within the same species (Edvardsen and Paasche, 1998 and references therein), however, little is known of the factors triggering toxicity. At least, phosphate deficiency (Edvardsen et al., 1990; Edvardsen, 1993), cellular N:P ratio (Johansson and Granéli, 1999) as well as growth phase and $\mathrm{pH}$ (Schmidt and Hansen, 2001) are known to influence toxicity of $C$. polylepis.

Field and laboratory experiments demonstrated that $C$. polylepis inhibited the activity of a broad range of planktonic organisms, including bacteria, heterotrophic protists, copepods and other algae as well (Carlsson et al., 1990; Nielsen et al., 1990; Tobiesen, 1991; Myklestad et al., 1995; Schmidt and Hansen, 2001). In laboratory experiments using protistan grazers, Carlsson et al. (1990) showed that the grazing activity of the tintinnid Favella ehrenbergii on Heterocapsa triquetra was negatively influenced by the addition of $C$. polylepis. In the case of the heliozoan Heterophrys marina, the rapid growth, which had been observed at $C$. polylepis concentrations of $2 \times 10^{3}$ cells $\mathrm{ml}^{-1}$, decreased with increasing $C$. polylepis concentrations, coming to a complete halt at around $75 \times 10^{3}$ cells ml $^{-1}$ (Tobiesen, 1991). An adverse effect on $H$. marina even at low $C$. polylepis concentrations was indicated by the fact that other, non-toxic food organisms permitted more rapid cell growth (Tobiesen, 1991).

However, it can not easily be ruled out that harmful effects of senescent dense algal cultures on test organisms might be caused by factors other than toxins, e.g. by high $\mathrm{pH}$ in the culture medium (Schmidt and Hansen, 2001). In addition, in comparative studies using different algal species as food, it is difficult to link causatively differences in growth and grazing activity to algal toxicity, as cell properties other than toxin content, such as size, cell shape or swimming speed, are important factors determining grazing efficiency (e.g. Hansen, 1992; Buskey, 1997; Tillmann and Reckermann, 2002). An elegant way to overcome these problems is to compare grazing on clones of the same algal species, which are virtually identical in all aspects except toxicity (Teegarden, 1999).

In the present paper, we therefore conducted grazing experiments with two different clones of $C$. polylepis that differ in toxicity (as defined by their toxic effects on Artemia franciscana) using the heterotrophic dinoflagellate Oxyrrhis marina as grazer. In order to understand the mode of toxin action, detailed knowledge on the chemical identity of the reactive compounds is a prerequisite. Therefore, lipid classes and fatty acids of both algal clones were analysed and compared in order to follow the hypothesis that toxicity of $C$. polylepis is caused by liposaccharide, lipids, or fatty acids (Yasumoto et al., 1990; Simonsen and Moestrup, 1997).

\section{Material and methods}

\subsection{Cultures}

The experiments were conducted with two haploid clones of $C$. polylepis Manton et Parke, named B1511 and B11. Both clones were isolated by Bente Edvardsen from a toxic strain B1, which was isolated from the Oslo Fjord (Norway). Each clone represents one of the two different cell types of $C$. polylepis described in detail by Paasche et al. (1990), Edvardsen and Paasche (1992), Edvardsen and Vaulot (1996) and Edvardsen and Medlin (1998). Briefly, both cell types are virtually indistinguishable with light microscopy, but electron microscopy observation has shown differences in form of fine structure of the organic scales covering 
the cells. Based on the original description by Manton and Parke (1962) one cell type was termed authentic $(\alpha)$, whereas the second type was termed alternate ( $\beta$ ) (Edvardsen and Paasche, 1992). The clone B1511 consists authentic cells, whereas the clone B11 contained only cells of the alternate type (Edvardsen and Vaulot, 1996). Both clones were grown in axenic batch cultures in IMR 1/2 medium (Eppley et al., 1967), supplemented with selenite (Dahl et al., 1989) under controlled conditions of $15{ }^{\circ} \mathrm{C}$ with artificial light of $45 \mu \mathrm{mol} \mathrm{m}{ }^{-2} \mathrm{~s}^{-1}$ and a light/dark cycle of $14: 10$. The heterotrophic dinoflagellate $O$. marina (Göttingen culture collection, strain B21.89) was grown under the same conditions with Dunaliella sp. as food.

\subsection{Artemia test}

Artemia tests were performed following the protocol of the Artemia Reference Centre (ARC Gent, Belgium) with slight modifications. Approximately $100 \mathrm{mg}$ of A. franciscana cysts (Batch No. AF/N2000) were incubated for $48 \mathrm{~h}$ in $500 \mathrm{ml}$ IMR $1 / 2$ under constant light at room temperature and moderate aeration to achieve continuous suspension and at least $90 \%$ oxygen saturation. After $48 \mathrm{~h}$, an aliquot of Artemia nauplii was collected in a petri dish and 20-30 instar II nauplii were transferred with approximately $50 \mu \mathrm{l}$ into each well of a 24 well plate (Nunc). The well was filled with $2 \mathrm{ml}$ of IMR $1 / 2$ (control) or varying concentrations of algal culture. All tests were done in triplicate. After $24 \mathrm{~h}$ in darkness at room temperature, living and dead nauplii in each well were counted. Death of nauplii was defined as non-motility for more than $10 \mathrm{~s}$. The corresponding mortality was transformed into probit units (Hewlett and Placklet, 1979) and plotted against log-transformed cell concentration. The algal concentration causing $50 \%$ mortality of A. franciscana $\left(\mathrm{LC}_{50}\right)$ were determined from the regression line, where a probit of five corresponds to $50 \%$ mortality.

\subsection{Lipid determination}

Five litres of algal culture were collected by centrifugation and stored at $-80^{\circ} \mathrm{C}$ until analysed. The algal pellet was resuspended in dichlormethane: methanol (2:1 by volume) and sonicated for $3 \mathrm{~min}$ with a stainless-steel probe. After the sonication the suspension was washed in $0.88 \% \mathrm{KCl}$. Lipid classes composition was analysed using thin layer chromatography (TLC) according to Olsen and Henderson (1989) using the standards for each lipid class obtained from Sigma, UK. For the determination of fatty acids, the algal extracts extracted as described above were transmethylated in methanol containing $2 \%$ sulphuric acid for $4 \mathrm{~h}$ at $80^{\circ} \mathrm{C}$ to produce fatty methyl esters (FAMEs) (Kattner and Fricke, 1986). FAMEs were extracted with hexane and analysed by gas liquid chromatography.

\subsection{Grazing and growth of Oxyrrhis marina}

A first experiment was carried out in order to follow batch culture growth and initial grazing of $O$. marina when fed each clone of $C$. polylepis. The $10 \mathrm{ml}$ of a dense culture of $O$. marina were mixed with $C$. polylepis in triplicate in $200 \mathrm{ml}$ Erlenmeyer flasks resulting in final concentrations of $0.55 \times 10^{3}$ and $20 \times 10^{3} \mathrm{ml}^{-1}$ for predator and prey, respectively. The O. marina culture had been precultured with Duniella, but was starved for 2 days prior to the onset of the experiment. Flasks containing phytoplankton only served as control. All flasks were incubated at $15^{\circ} \mathrm{C}$ at an irradiance of $45 \mu \mathrm{mol}$ quanta $\mathrm{m}^{-2} \mathrm{~s}^{-1}$ and a photoperiod of 14L:10D. For cell counts, subsamples were taken twice a day. O. marina was counted in $1 \mathrm{ml}$ lugol-fixed subsamples with an inverted microscope, whereas $C$. polylepis cell numbers were estimated using a Coulter Counter Model II. Division rate $\mu$ (per day) was calculated from the regression coefficient of ln cell number versus time. For elemental analysis, triplicate subsamples of control flasks (C. polylepis only) were gently filtered onto precombusted GF/C filters, gently treated with $3-5$ drops of $0.1 \mathrm{~N} \mathrm{HCl}$, dried at $60^{\circ} \mathrm{C}(24 \mathrm{~h})$ and combusted in a Carlo-Erba NA 1500 elemental analyser. In order to quantify ingestion, $1 \mathrm{ml}$ subsamples were taken at times $0,0.5,1,1.5$, 2, 2.5, 3, 4, 6, 22 and $46 \mathrm{~h}$. Samples were fixed with $1 \%$ glutaraldehyde and inspected under an inverted microscope. For at least 100 O. marina per sample it was scored whether the grazer had ingested algal cells (regardless the exact number of ingested cells). From that data, the probability of a grazer not having ingested any prey cell could be calculated. Data were fitted by non-linear regression to the equation $\left(P_{0(t)}=\right.$ $\left.(1-z) \mathrm{e}^{-\lambda t}+z\right)$, assuming that the sample distribution fit a Poisson with extra zeros (Bratvold et al., 2000). 
The $z$ is the fraction of the population that do not feed at all and $\lambda$ is the Poisson parameter in units of ingested food cells per grazer per hour (Bratvold et al., 2000). In addition, in samples taken after 22 and $46 \mathrm{~h}$ the number of algal cells inside food vacuoles of at least 100 grazers was estimated and divided in categories of $<5,5-10,10-20$ and $>20$ algal cells per grazer.

A second experiment was conducted to determine the grazing and growth response of $O$. marina as a function of algal food concentration. A series of equivalent grazer inoculate (final concentration: $760 \mathrm{ml}^{-1}$ ) was exposed to six different food densities ranging from 0 to $400 \times 10^{3} \mathrm{ml}^{-1}$. Different food concentrations were established by appropriate dilution of a exponential batch culture of $C$. polylepis. Three replicates were set up for each food concentration. Triplicate flasks containing the same concentrations of phytoplankton only served as control. At time $t=0$ initial samples were taken for determination of cell concentrations. After $2 \mathrm{~h}$ incubation, $1 \mathrm{ml}$ subsamples were taken for the determination of initial grazing rates and fixed with $1 \%$ glutaraldehyde. After settlement in $1 \mathrm{ml}$ Utermöhl chambers, samples were inspected under an inverted microscope using fluorescence light (Zeiss filter set 14). Counts of the number of ingested algal cells of at least 200 individuals of $O$. marina allowed for the determination of initial grazing rate (algae per grazer per hour). Final samples for determination of cell numbers were taken $48 \mathrm{~h}$ after initial sampling. Final samples were fixed with lugol's solution and grazer cells were counted microscopically. In each final sample as well as in initial samples, the cell size of at least 20 lugol-fixed grazers was measured by means of a calibrated ocular micrometer. Size of both $C$. polylepis clones was estimated using a Coulter Counter Multisizer II. From size measurements, cell volumes were calculated using a prolate spheroid and a sphere as geometric shape for $O$. marina and C. polylepis, respectively. Algal cell concentration of experimental and control flasks were estimated using a Coulter Counter Multisizer II, except for final counts for the two lowest food concentration. In these samples, algal cells were counted microscopically as algal density were two low for a reliable estimation by Coulter Counter. Division rate, ingestion and clearance for the $48 \mathrm{~h}$ period were calculated using the equations of Frost (1972) and Heinbokel (1978). Apparent gross growth efficiency (aGGE) was calculated as the grazer biomass produced per algal biomass consumed using measured $C$. polylepis carbon values, calculated volume of $O$. marina and a C:cell-volume conversion factor of 0.14 (Lessard, 1991). All rates are plotted against initial food concentrations. In order to perform grazing experiments with a mixture of both clones, an attempt was made to stain $C$. polylepis with the vital green fluorescent stain 5-chloromethylfluorescein diacetate (CMFDA) according to $\mathrm{Li}$ et al. (1996) with slight modifications. Dense $C$. polylepis cultures were stained with a final dye concentrations of $1 \mu \mathrm{M}$ CMFDA for $3 \mathrm{~h}$.

\section{Results}

Both strains were tested for their toxicity to A. franciscana nauplii. No mortality of Artemia was observed for the seawater control as well as for the strain B11 up to the highest test concentration of $4 \times 10^{5}$ cells ml $^{-1}$. When exposed to the strain B1511, however, mortality of Artemia was high resulting in a $24 \mathrm{~h} \mathrm{LC}_{50}$ of 4132 cells $\mathrm{ml}^{-1}$ (Fig. 1). In contrast to this marked difference in toxicity, no obvious differences in fatty acid composition between the two clones were detected. For both strains, 18:5 $\left(\omega_{3}\right), 20: 5\left(\omega_{3}\right)$ and 22:6 $\left(\omega_{3}\right)$ fatty acids were predominant (Table 1$)$. With respect

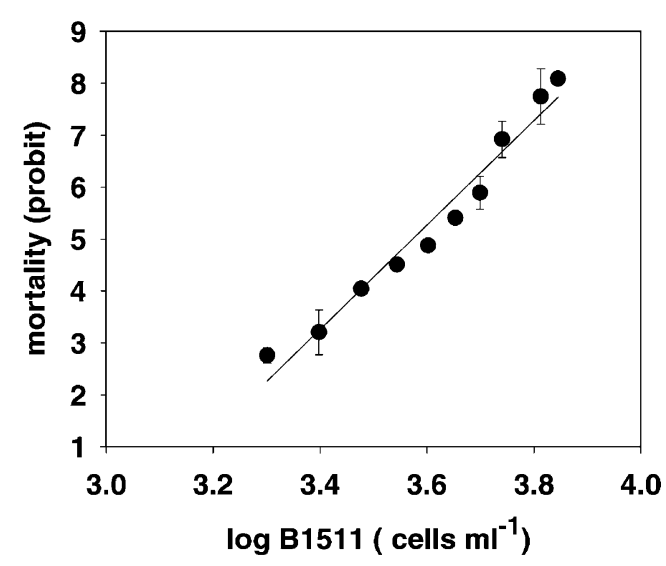

Fig. 1. Probit transformed percentage mortality of Artemia franciscana nauplii as a function of log cell concentration of Chrysochromulina polylepis, clone B1511. Data points represent triplicate mean \pm 1 S.D. Probit value 5 represents $50 \%$ mortality and corresponds to the $24 \mathrm{~h} \mathrm{LC}_{50}$ value of 4132 cells $\mathrm{ml}^{-1}\left(r^{2}=0.988\right)$. 
Table 1

Fatty acids composition of the toxic clone B1511 and the non-toxic clone B11 of $C$. polylepis. Data represent triplicate mean \pm 1 S.D.

\begin{tabular}{lrr}
\hline Fatty acid & \multicolumn{1}{c}{ B11 $(\%)$} & B1511 (\%) \\
\hline $14: 0$ & $10.1 \pm 0.7$ & $12.2 \pm 1.1$ \\
$15: 0$ & $1.7 \pm 0.3$ & $1.6 \pm 0.2$ \\
$16: 0$ & $13.1 \pm 1.1$ & $11.2 \pm 0.9$ \\
$16: 1$ & $1.8 \pm 0.1$ & $3.1 \pm 0.3$ \\
$16: 2(n-6)$ & $1.2 \pm 1$ & $1.3 \pm 1.0$ \\
$16: 3(n-3)$ & $1.2 \pm 0.1$ & $1.2 \pm 0.4$ \\
$16: 4$ & $1.5 \pm 0.2$ & $1.3 \pm 0.8$ \\
$18: 1(n-9)$ & $3.4 \pm 0.6$ & $3.2 \pm 0.5$ \\
$18: 1(n-7)$ & $4.0 \pm 0.3$ & $5.3 \pm 0.3$ \\
$18: 2(n-6)$ & $1.3 \pm 0.1$ & $0.9 \pm 0.5$ \\
$18: 4(n-3)$ & $6.1 \pm 1.2$ & $8.5 \pm 1.6$ \\
$20: 1$ & $1.1 \pm 0.1$ & $1.0 \pm 0.1$ \\
$18: 5(n-3)$ & $18.6 \pm 2$ & $15.7 \pm 3.6$ \\
$20: 4(n-3)$ & $0.7 \pm 0.01$ & $1.9 \pm 0.2$ \\
$20: 5(n-3)$ & $18.8 \pm 2.8$ & $17.5 \pm 3.2$ \\
$22: 1(n-11)$ & $1.5 \pm 0.4$ & $1.3 \pm 0.3$ \\
$22: 6(n-3)$ & $14.1 \pm 1.7$ & $12.8 \pm 2.1$ \\
\hline
\end{tabular}

to lipid classes, again no obvious differences between the two clones could be detected (Table 2). Elemental analysis revealed slightly higher carbon and nitrogen content for the non-toxic clone B11 compared with the toxic clone B1511 (Table 3). Based on Coulter counter size measurement, the median size of the two C. polylepis clones was 6.65 and $6.31 \mu \mathrm{m}$, respectively. Due to these differences in size, the calculated ratio of carbon to volume was nearly the same for both clones (Table 3).

After inoculating starved $O$. marina with $C$. polylepis cultures, the dinoflagellate immediately started to ingest algal cells. The time series of estimates of the percentage of $O$. marina not having ingested algal cells, however, shows clear differences between the two C. polylepis clones (Fig. 2). The numbers of Oxyrrhis feeding on the non-toxic clone
Table 3

Comparison of cellular properties of the toxic clone B1511 and the non-toxic clone B11 of C. polylepis (error terms represents standard deviation, $n=3$ )

\begin{tabular}{|c|c|c|}
\hline Chryschromulina polylepis & $\mathrm{B} 11$ & B1511 \\
\hline Toxicity to Artemia nauplii & No & Yes \\
\hline $\mathrm{C}$ content $\left(\mathrm{pg}\right.$ cell $\left.^{-1}\right)$ & $55.07 \pm 0.85$ & $48.87 \pm 0.48$ \\
\hline $\mathrm{N}$ content $\left(\mathrm{pg}\right.$ cell $\left.^{-1}\right)$ & $7.81 \pm 0.10$ & $5.93 \pm 0.03$ \\
\hline $\mathrm{C}: \mathrm{N}(\mathrm{g}: \mathrm{g})$ & $7.05 \pm 0.03$ & $8.24 \pm 0.09$ \\
\hline Cell volume $\left(\mu \mathrm{m}^{3}\right)$ & 153.9 & 131.6 \\
\hline $\mathrm{C} /$ volume $\left(\mathrm{pg} \mu \mathrm{m}^{-3}\right)$ & 0.36 & 0.37 \\
\hline Median cell size $(\mu \mathrm{m})$ & 6.65 & 6.31 \\
\hline Division rate $\mu$ (per day) & 0.51 & 0.40 \\
\hline
\end{tabular}

B11 increased sharply with time (i.e. the probability having no ingested prey decreased), whereas ingestion of the toxic clone B1511 is much slower. Calculation of the grazing rates from a probability of zero curve

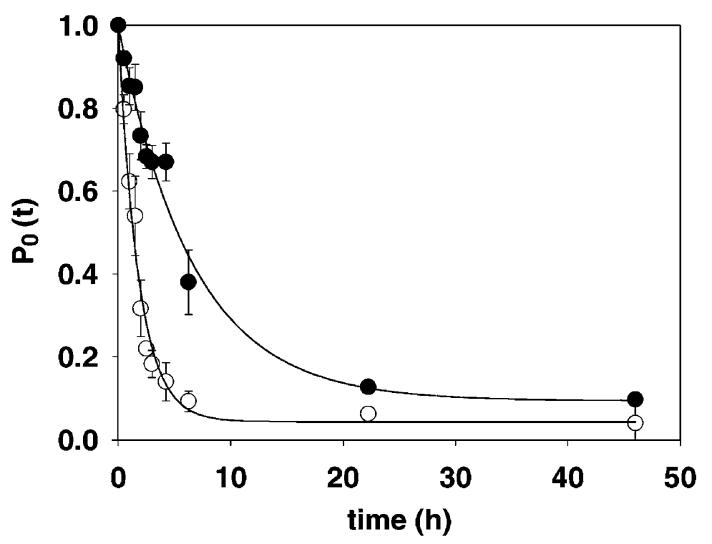

Fig. 2. Probability of $O$. marina having no ingested prey at time $t$ when fed with the toxic clone B1511 (closed circles) or the non-toxic clone B11 (open circles) of C. polylepis. Data points represent triplicate mean \pm 1 S.D. Data were fitted to the equation $\left(P_{0(t)}=(1-z) \mathrm{e}^{-\lambda t}+z\right)($ see Section 2$)$.

Table 2

Lipid class composition (\% total lipid) of the toxic clone B1511 and the non-toxic clone B11 of C. polylepis (n.d.: not detected)

\begin{tabular}{llll}
\hline Lipid classes & Abbreviation & B11 (\%) & B1511 (\%) \\
\hline Phosphatidylcholine & PC & 43.4 & 47.9 \\
Phophatidylinositol & PI & 0.6 & 1.3 \\
Phosphatidylethanolamin/phosphatidylglycerol & PE/PG & 3.9 & 7.4 \\
Diagalactosyldiacylglycerol & DGDG & 31.5 & 27.4 \\
Sulfoquinovosyldiacylglycerol & Sulf & n.d. & n.d. \\
Monogalactosyldiacylglycerol & MGDG & 6.5 & 5.5 \\
Triacylglycerol & TAQ & 14.1 & 10.4 \\
\hline
\end{tabular}



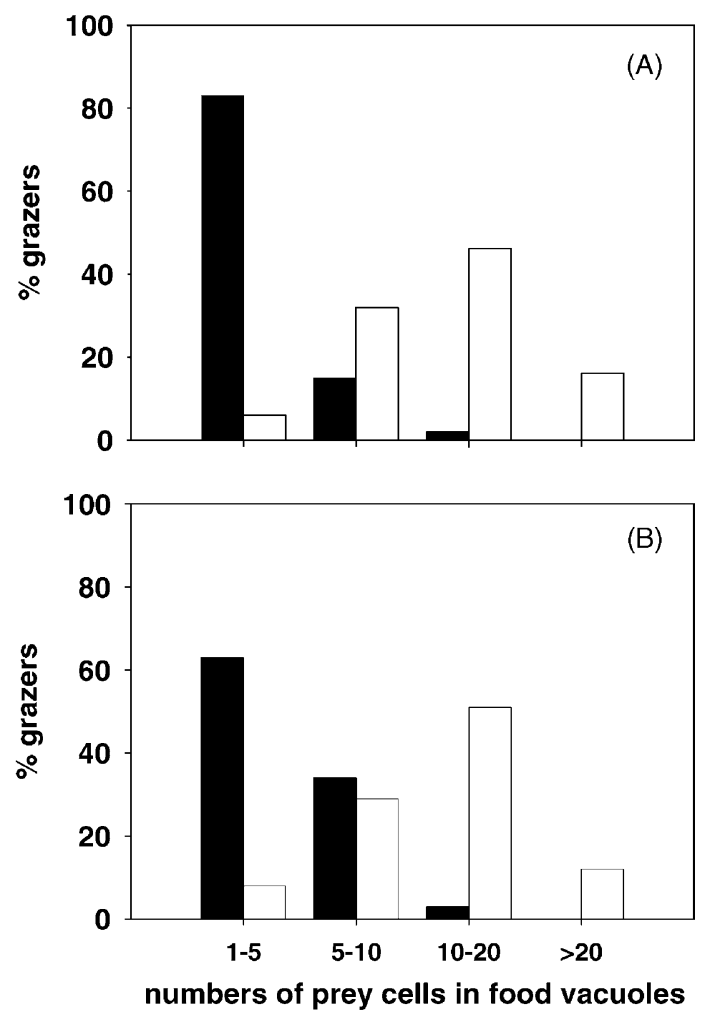

Fig. 3. Percentage distribution of $O$. marina with different numbers of ingested prey cells in food vacuoles when fed with the toxic clone B1511 (closed bars) or non-toxic clone (open bars) of $C$. polylepis. (A) after $22 \mathrm{~h}$ of incubation; (B) after $46 \mathrm{~h}$ of incubation.

$\left(P_{0(t)}=(1-z) \mathrm{e}^{-\lambda t}+z\right)$ revealed $\lambda$ as the grazing rate to be 0.55 and 0.15 algae per grazer $h^{-1}$ for the non-toxic and toxic clone, respectively. The $z$, is the percentage of $O$. marina not feeding at all, was estimated to be about 5 and $10 \%$ for the non-toxic and toxic clone, respectively. A reduced grazing on the toxic clone is also evident when comparing the numbers of ingested cells after 22 and $46 \mathrm{~h}$ of incubation (Fig. 3). Most of $O$. marina feeding on the toxic clone had ingested 1-5 algal cells, whereas few grazers were observed with 10 or more algal cells inside food vacuoles. In contrast, most of $O$. marina feeding on the non-toxic clone had ingested 10-20 algal cells after 22 or $46 \mathrm{~h}$ of incubation. Whereas cell numbers in ungrazed control bottles of the non-toxic clone B11 increased exponentially with time $(\mu=0.51$ per day), grazing in the experimental bottles led to
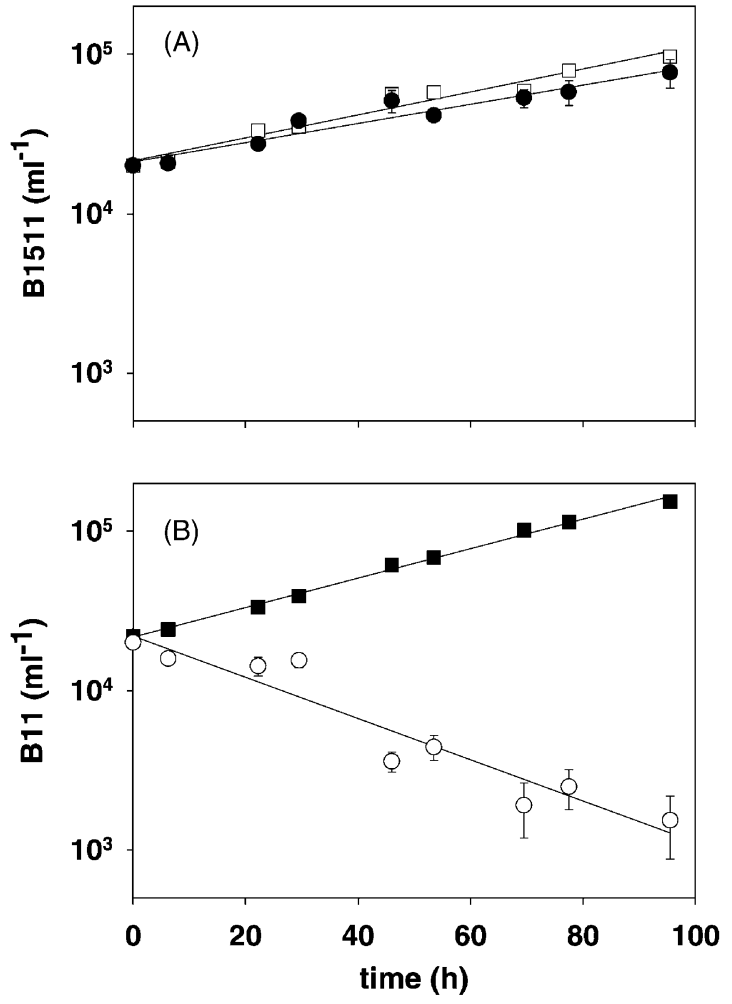

Fig. 4. Growth curves of $C$. polylepis. (A) the toxic clone B1511 grown with $O$. marina (closed circles: $\mu=0.33$ per day; $r^{2}=0.931$ ) and grown in monoculture (open squares: $\mu=0.40$ per day; $\left.r^{2}=0.959\right)$. (B) the non-toxic clone B11 grown with $O$. marina (open circles: $\mu=-0.72$ per day; $r^{2}=0.911$ ) and grown in monoculture (closed squares: $\mu=0.51$ per day; $r^{2}=0.996$ ). Data points represent triplicate mean \pm 1 S.D.

a strong declined of algal numbers down to about $10^{3} \mathrm{ml}^{-1}$ (Fig. 4). Growth rate of the toxic clone B1511 in ungrazed control bottles ( $\mu=0.40$ per day) was comparable to the growth rate of the non-toxic clone. For B1511, however, growth rate in presence of $O$. marina as grazer was only slightly depressed ( $\mu=0.33$ per day, Fig. 4A). Growth curves of $O$. marina are presented in Fig. 5. Cell numbers of $O$. marina increased exponentially during the whole period in both treatments. However, growth rate of $O$. marina with the toxic strain as food $(\mu=0.22$ per day) was obviously lower compared with the growth rate with the non-toxic clone ( $\mu=0.38$ per day). Under identical incubation conditions $O$. marina reached a growth rate of $\mu=0.45$ per day when Dunaliella sp. was offered as food algae (data not shown). 


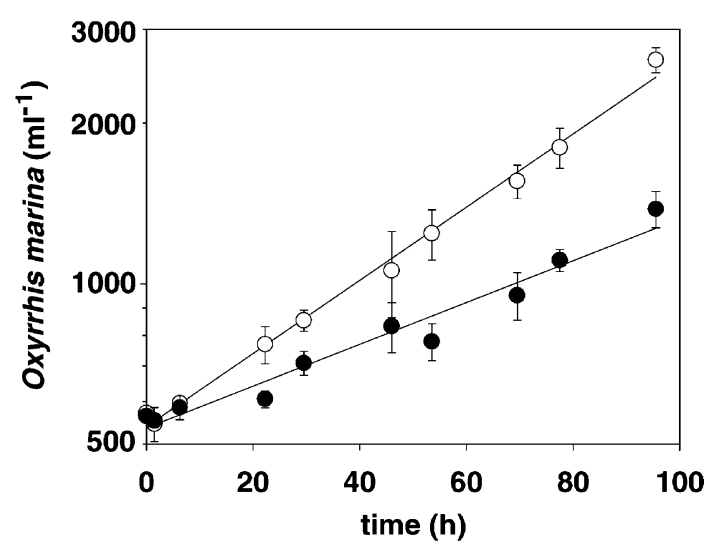

Fig. 5. Growth curves of $O$. marina when fed with the toxic clone B1511 (closed circles: $\mu=0.22$ per day; $r^{2}=0.962$ ) or the non-toxic clone B11 (open circles: $\mu=0.38$ per day; $r^{2}=0.995$ ) of $C$. polylepis. Data points represent triplicate mean \pm 1 S.D.

In the $48 \mathrm{~h}$ incubation experiment using different initial $C$. polylepis concentrations, phytoplankton in control bottles increased on average to $143 \%$ in respect of the start concentration. In experimental bottles of the toxic clone B1511, final algal cell concentration accounted for $135 \%$ of the start concentration. In contrast, the non-toxic clone B11 was reduced to 1,14 and $75 \%$ of the start concentration for the three lowest algal concentrations $\left(20 \times 10^{3}\right.$ to $\left.100 \times 10^{3} \mathrm{ml}^{-1}\right)$, respectively and remained nearly constant for the two

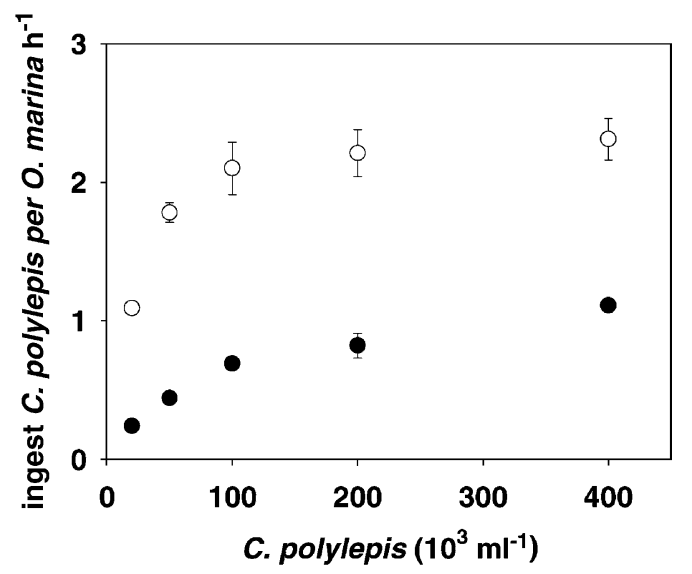

Fig. 6. Initial ingestion rate of $O$. marina (fluorescence counts of ingested algae after $2 \mathrm{~h}$ of incubation) as a function of initial food concentration when fed with the toxic clone B1511 (closed circles) or the non-toxic clone B11 (open circles). Data points represent triplicate mean \pm 1 S.D. highest concentrations (data not shown). Ingestion was estimated using two different approaches. The initial grazing rates of starved $O$. marina, as estimated by fluorescence microscopy, are presented in Fig. 6. For both $C$. polylepis clones, ingestion rate of $O$. marina increased with increasing food concentration until it became saturated at about $100 \times 10^{3} \mathrm{ml}^{-1}$. However, both the initial increase as well as highest ingestion rate at food saturation were obviously lower when fed with the toxic clone B1511. Ingestion rates calculated using the decline of food cells during the $48 \mathrm{~h}$ incubation period showed the same pattern (Fig. 7A), although values are generally lower by a factor of about 2. Clearance calculated for $O$. marina feeding on the non-toxic clone of $C$. polylepis showed the typical
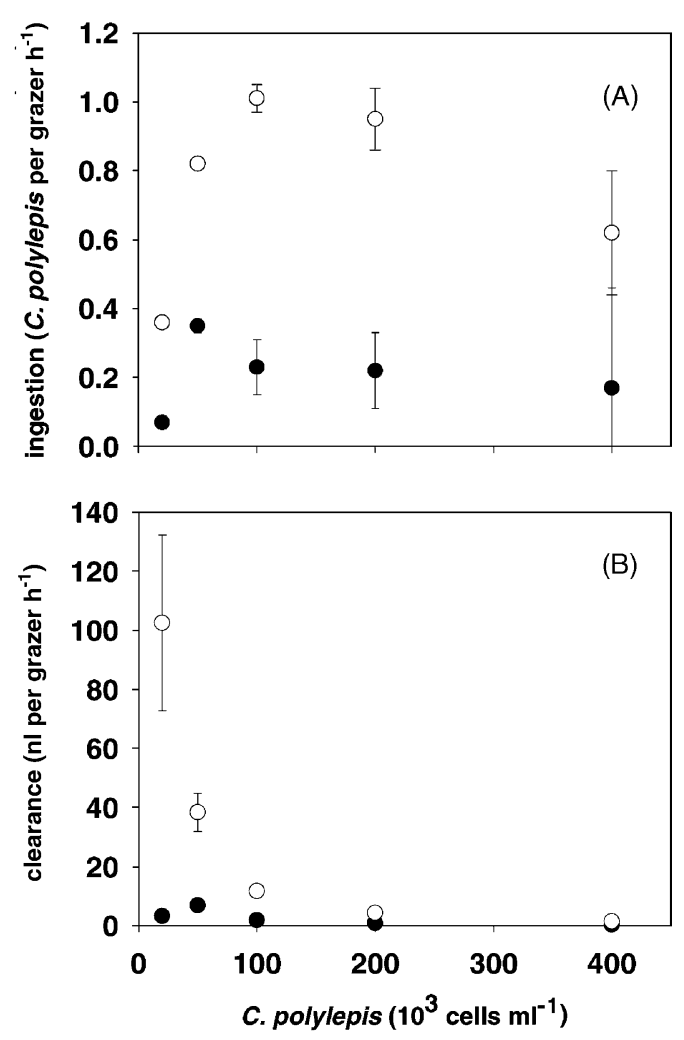

Fig. 7. Ingestion and clearance of $O$. marina as a function of initial food concentration, calculated according to Frost (1972) for a $48 \mathrm{~h}$ incubation period. Data point represent triplicate mean \pm 1 S.D. (A) Ingestion of $O$. marina when fed with the toxic clone B1511 (closed circles) or the non-toxic clone B11 (open circles). (B) Clearance of O. marina when fed with the toxic clone B1511 (closed circles) or the non-toxic clone B11 (open circles). 

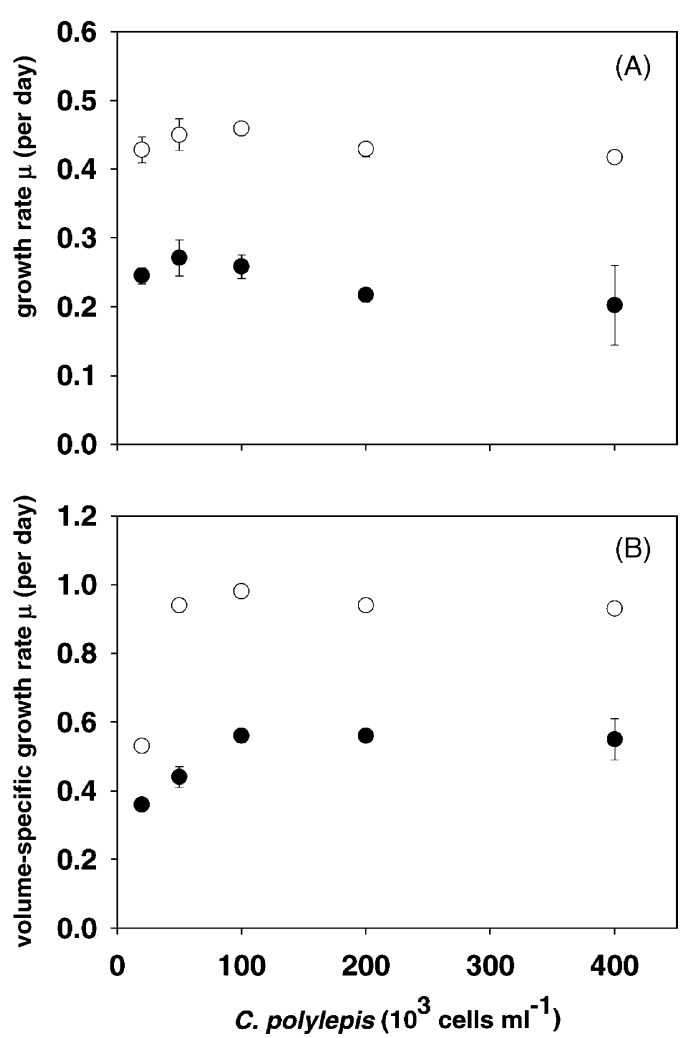

Fig. 8. Growth of $O$. marina as a function of initial food concentration when fed with the toxic clone B1511 (closed circles) or the non-toxic clone B11 (open circles). Data point represent triplicate mean \pm 1 S.D. (A) Division rate of $O$. marina calculated from the increment of cell numbers. (B) Growth rate calculated from the increment of total $O$. marina volume.

pattern with numbers increasing at low food concentration up to $102 \mathrm{nl}$ per grazer $\mathrm{h}^{-1}$. When fed with the toxic clone, calculated clearance rates of $0.4-7 \mathrm{nl}$ per grazer $\mathrm{h}^{-1}$ remains remarkably low for all food concentrations tested (Fig. 7B). Maximum specific division rates of $O$. marina were 0.46 and 0.27 per day for the non-toxic and toxic clone, respectively. However, with both algal clones as food, division rate of $O$. marina was almost constant over the whole range of different food concentrations (Fig. 8A). This is mainly because of size differences of $O$. marina in the different treatments (data not shown). When growth is calculated on the basis of an increase in total volume of $O$. marina (Fig. 8B) both curves show the typical increase of specific growth rate with increasing food concentration. However, volume-specific growth

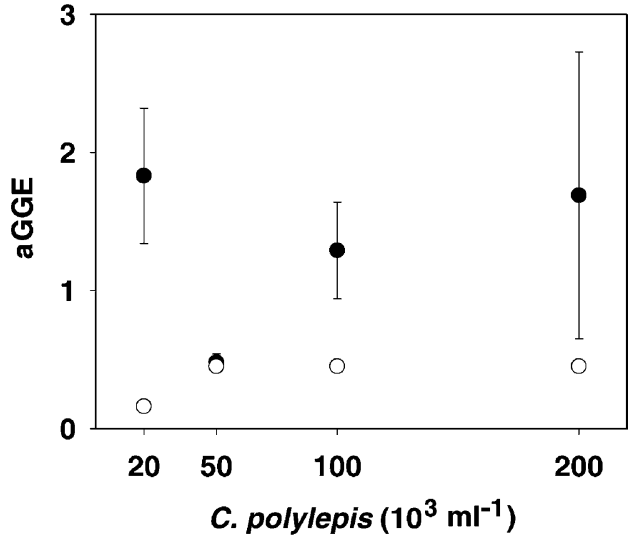

Fig. 9. Apparent gross growth efficiency (aGGE) of $O$. marina as a function of initial food concentration when fed with the toxic clone B1511 (closed circles) or the non-toxic clone B11 (open circles). Data point represent triplicate mean \pm 1 S.D.

rate is explicitly higher compared with division rate based on the increase of cell numbers, probably reflecting an overall increase of cell volume of starved $O$. marina in the consequence of food supply. Based on the calculated biomass increase of $O$. marina and total algal carbon ingested, the aGGE was calculated (Fig. 9). The aGGE is plotted for food concentration up to $200 \times 10^{3} \mathrm{ml}^{-1}$, as numbers calculated for the highest food concentration were erratically high. For the non-toxic clone B11, aGGE ranging from 0.16 to 0.45 had low standard deviations and was relatively constant for higher algal concentrations. For the toxic clone B1511, however, the calculation yielded highly scattered aGGE values predominantly above the theoretical maximum value of one (see Section 4).

Grazing experiments using a mixture of both clones as prey, one of them stained with the live stain CMFDA, were unsuccessful. As frequently observed under the microscope, intense staining of $C$. polylepis, concentrated in the posterior part of the cell, was lost spontaneously, probably due to leakage or excretion. Hence, a reliable application of this technique was not possible.

\section{Discussion}

In the present study, the feeding efficiency of $O$. marina on two different clones of $C$. polylepis was 
analysed. The basic assumption for the interpretation of our grazing experiments is that, from the grazers perspective, both clones are virtually identical except toxicity. In fact, the two clones representing different cell types (see Section 2) at least differ slightly with respect to the morphology of body scales (Paasche et al., 1990; Edvardsen and Paasche, 1992). However, nothing is known if these small morphological differences might influence feeding interaction, e.g. by prey recognition and/or handling. Among the main known prey features affecting ingestion are size and motility (e.g. Hansen et al., 1994; Buskey, 1997; Tillmann and Reckermann, 2002). Although motility was not explicitly quantified, qualitative microscopical observation revealed no basic differences between the two clones of $C$. polylepis with respect to swimming behaviour and/or swimming speed. Size may play an important role for food selection of $O$. marina (Hansen et al., 1996). Initial flow cytometric analysis of Edvardsen and Paasche (1992) indicated size differences between both cell types with the alternate cell type about twice the size of the authentic cell type. For the two clones used in the present study, size measurements using a Coulter Counter revealed only minor differences in median cell size (Table 3) and, hence, in calculated cell volume. Hansen et al. (1996) observed a shift in the size spectrum of a single food algae as a result of $O$. marina grazing activity and interpreted this as size selective grazing even within small size differences. However, it is well known that protistan grazers release faecal particles (Nöthig and Bodungen, 1989; Elbrächter, 1991; Tillmann and Reckermann, 2002) that may overlap in size with their algal food. Particle production may thus confound results of experiments using a Coulter Counter in respects to particle size selectivity (Stoecker, 1984). We therefore argue that the rather small differences in size between the two C. polylepis clones are unlikely to be the cause of the large differences in grazing rate of $O$. marina.

The crucial difference between the two clones tested is their toxicity to nauplii of A. franciscana. This is in accordance with results of Edvardsen and Paasche (1992), who found a culture containing 90\% alternate cells to be only slightly toxic to Artemia nauplii $(24 \mathrm{~h}$ $\mathrm{LC}_{50}>350 \times 10^{3}$ cells ml ${ }^{-1}$ ), whereas $24 \mathrm{~h} \mathrm{LC}_{50}$ of cultures containing $100 \%$ authentic cells was about $2.6 \times 10^{3}$ cells $\mathrm{ml}^{-1}$. A culture apparently containing $100 \%$ alternate cells appeared non-toxic to Artemia at concentrations up to $100 \times 10^{3} \mathrm{ml}^{-1}$, whereas authentic cells had a $24 \mathrm{~h} \mathrm{LC}_{50}$ of $6.9 \times 10^{3} \mathrm{ml}^{-1}$ (Edvardsen, 1993). This is close to our estimate of toxicity of clone B 1511 with a $24 \mathrm{~h} \mathrm{LC}_{50}$ of $4.2 \times 10^{3}$ cells ml $^{-1}$, which is also in the range of estimated made by Simonsen and Moestrup (1997). The differences in toxin content/production between the two $C$. polylepis clones used in our experiments are probably the cause of the small differences in cellular nitrogen content and growth rate (Table 3), which per se are unlikely to be the cause of the large differences in grazing rate of $O$. marina.

To conclude, we feel safe to argue that both strains are nearly identical except for their toxicity, implying that clone-specific differences in grazing and growth of the predator are causatively linked to toxicity effects.

Profound quantitative differences in grazing and growth of $O$. marina when fed the two clones of $C$. polylepis were apparent in all experiments (experiment 1: Figs. 2, 3 and 5; experiment 2: Figs. 6-8). However, the shape of the numerical and functional response curves for the two clones was quite similar. The growth rate of $O$. marina was never inhibited with increasing concentrations of the toxic clone B1511, even up to concentrations of $4 \times 10^{5}$ cells $\mathrm{ml}^{-1}$ (Fig. 8). Therefore, it must be concluded that negative effects to the grazers are not related to the algal concentration and hence not to the concentration of a tentative toxin released into the water. Rather, grazing inhibition seems to be related to each single feeding process; $O$. marina apparently avoided ingestion of the toxic clone. This might be because of reception of some toxin-related properties of the algal cell like "smell", as chemosensory capabilities are well known among heterotrophic dinoflagellates (Hauser et al., 1975; Spero, 1985; Buskey, 1997). Nevertheless, ingestion of toxic cells was not totally suppressed. This might be because of the fact that no other particulate food was available and $O$. marina was starved prior to the experiments, as starved $O$. marina have been shown to be less selective (Tarran, 1991). There is no evidence that toxic cells, after being ingested, caused grazing inhibition or substantial harm to the grazer. The number of grazers having ingested prey cells after only $30 \mathrm{~min}$ of incubation was obviously lower when incubated with the toxic clone B1511 (Fig. 2) making an involvement of internal toxication unlikely. Moreover, although the number of ingested toxic cells 
increased three-fold with increasing food concentrations (Fig. 7), the corresponding volume-specific growth rate did not decrease, as would be expected in consequence of lethal effects of incorporated toxins.

From an ecological point of view it is an important difference whether a toxic algae is avoided by a predator or a predator is eliminated by toxins. In the first case, predators are able to continue feeding on other co-existing phytoplankton species, thereby releasing the toxic species from competition. In addition, grazing on other algae and subsequent DOC release (Strom et al., 1997) might stimulate the growth of bacteria, which in turn can be taken up by mixotrophic algae (Jones et al., 1993; Nygaard and Tobiesen, 1993). In the last case, elimination of grazers is also a relief for competing algal species, making it more difficult to explain the formation of monospecific blooms. The results presented above clearly showed that $O$. marina was not killed by the presence or by the ingestion of toxic C. polylepis. This is in line with results presented by Carlsson et al. (1990) and Nielsen et al. (1990), who showed that mortality of the tintinnid $F$. ehrenbergii upon addition of $C$. polylepis came close to but never surpassed the population decline because of pure starvation. Growth rate of the heliozoa $H$. marina decreased at increasing $C$. polylepis concentrations approaching zero at concentrations above $75 \times 10^{3} \mathrm{ml}^{-1}$ (Tobiesen, 1991). However, H. marina cells survived and regained normal growth after transfer into fresh medium. From our experiments using monoculture prey it is impossible to state whether ingestion of other algae might be affected by the presence of toxic $C$. polylepis. Unfortunately, the attempt to perform grazing experiments with a mixture of both $C$. polylepis clones, one selectively stained with CMFDA, failed. It is important to note that growth of $O$. marina is less effected by the presence of toxic $C$. polylepis than ingestion. In experiment 1 , ingestion rate of $O$. marina fed with the toxic clone reached $27 \%$ of the rate estimated for $O$. marina feeding on the non-toxic clone, whereas the division rate of $\mathrm{O} . \mathrm{ma}$ rina fed the toxic clone was $58 \%$ of the division rate of $O$. marina fed the non-toxic clone. The corresponding numbers for experiment 2 (mean for all food concentrations) were 30 and 54\% for ingestion and division, respectively. The calculated numbers of the aGGE for $O$. marina feeding on the toxic clone above the theoretical maximum of 1 (Fig. 9) presented evidence that
O. marina mixed with the toxic clone may have used clumps of bacteria and detritus or dissolved organic substances present in the algal medium for growth. Oxyrrhis had been previously shown to be capable of growing in axenic medium, relying on osmotrophy to support growth (Droop, 1959). Thus, in the presence of toxic C. polylepis, O. marina seems to be able to switch to an alternate food source. Experiments using F. ehrenbergii fed with mixed algal cultures indicates that ingestion of the ciliate is generally suppressed by the presence of high concentrations of $C$. polylepis (Carlsson et al., 1990; Nielsen et al., 1990). With respect to copepods, Nielsen et al. (1990) observed no negative effect with Acartia tonsa feeding on palatable cells in experiments with mixtures of Rhodomonas baltica and different concentrations of cultivated $C$. polylepis. When incubated with natural populations of C. polylepis from the 1988 bloom, however, the mortality rate of copepods significantly increased. Clearly, more experiments using mixed algal cultures are needed to address the question whether grazers are eliminated or deterred by the $C$. polylepis toxin. Besides a reduction of grazing pressure, $C$. polylepis toxin may directly effect other algae as well. Whereas Riegman et al. (1996) ascribed the success of $C$. polylepis in multispecies culture experiments to the ability of $C$. polylepis to outcompete other algae, Schmidt and Hansen (2001) could recently show that toxins released by $C$. polylepis had a direct harmful effect on a whole range of tested algae in mixed cultures. This allelophatic activity, in addition to a reduced grazing pressure, may explain why a bloom like the one in 1988 in the North Sea became essentially monospecific at high cell concentrations. According to Schmidt and Hansen (Schmidt and Hansen, 2001), all but one autotrophic dinoflagellates tested were immobilised at $C$. polylepis concentrations of $1.9 \times 10^{5}$ cells $\mathrm{ml}^{-1}$. Although heterotrophic dinoflagellates might be expect to respond in a similar way, no signs of immobilisation of $O$. marina could be detected in our experiments. $O$. marina might be particularly resistant against $C$. polylepis toxin, although it has been shown to be rapidly immobilised by Alexandrium toxins (Tillmann and John, 2002). However, it is well known that different strains of $C$. polylepis may vary considerably with respect to their toxicity (Edvardsen and Paasche, 1998), which in addition might be regulated by phosphorous deficiency (Edvardsen et al., 
1990; Edvardsen, 1993), cellular N:P ratio (Johansson and Granéli, 1999) as well as growth phase and $\mathrm{pH}$ (Schmidt and Hansen, 2001). As Schmidt and Hansen did not perform Artemia tests, results can hardly be compared and differences in $C$. polylepis toxicity therefore might explain the different reaction of autotrophic and the heterotrophic dinoflagellate.

So far, toxicity of $C$. polylepis is defined towards a wide range of different bioassays, including haemolytic tests (e.g. Edvardsen et al., 1990; Eschbach et al., 2001), the standard Artemia test (Edvardsen, 1993), toxicity towards rat hepatocytes (Underdahl et al., 1989), the inhibition of the uptake of neutrotransmitters into synaptosomes and synaptic vesicles of rat brain (Meldahl et al., 1994), the immobilisation effect to $H$. triquetra (Schmidt and Hansen, 2001), or various negative effects towards a number of zooplankton grazers (Carlsson et al., 1990; Tobiesen, 1991, this study). However, there clearly is a need to identify chemically the toxic principle of C. polylepis. Screening for bioactive compounds in C. polylepis performed so far suggests that toxicity could be related to certain lipid classes or fatty acids. Based on chromatographic and mass spectral data of isolated haemolytic compounds, Yasumoto et al. (1990) suggested monoacyldigalactosylglycerol and octadecapentaenoic acid, to be implicated in the toxicity of $C$. polylepis. However, haemolytic compounds are quite common in several algal species without any substantial correlation between haemolytic activity and the toxicity in other bioassays (Yasumoto et al., 1987; Simonsen and Moestrup, 1997). Simonsen and Moestrup detected several haemolytic compounds in C. polylepis, but only one spot was toxic to Artemia (Simonsen and Moestrup, 1997). The authors suggested this substance characteristic of $C$. polylepis to be a liposaccharide. In our study, however, we found no obvious differences in the lipid classes and/or fatty acid composition between the toxic and non-toxic clones (Tables 1 and 2), suggesting that other compounds are likely responsible for the Artemia toxicity and grazer deterrent properties of $C$. polylepis. There are hints in the literature that $C$. polylepis produces toxins without hemolytic properties in addition to the haemolytic ones (Stabell et al., 1993). Thus, $C$. polylepis toxins-like other algal toxins might be a group of compounds (Underdahl et al., 1989), probably causing different toxic effects. Clearly, detailed comparative studies have to be carried out between the various bioassays for each purified toxic component in question.

Using a toxic and a non-toxic clone of one species is a powerful tool for comparative studies of the ecological impact and of chemical particularities of toxic algae. In the case of this study we could demonstrate a clear effect of the toxic C. polylepis clone to a microzooplankton grazer. The chemical composition with respect to lipid classes and fatty acids provided no hint for an involvement of these substances in the toxicity towards Artemia and O. marina. In the future, we will use this model of comparative studies for further chemical analysis to clarify the chemical identity of C. polylepis toxins. Further on, we will use molecular techniques to identify genes that are involved in the toxin production in order to study the environmental regulation of toxin production at the expression level.

\section{Acknowledgements}

Special thanks to Bente Edvarsen for providing the two clones of $C$. polylepis and also to Martin Graeve for his technical support in fatty acid and lipid analysis. This work was supported by the German BMBF (TEPS 03F0161) and the European Commission (Research Directorate General-Environment Programme-Marine Ecosystems) through the BIOHAB project "Biological control of Harmful Algal Blooms in European coastal waters: role of eutrophication" (contract no. EVK3-CT99-00015). The BIOHAB project is part of the EC EUROHAB cluster.

\section{References}

Bratvold, D., Scienc, F., Taub, S.R., 2000. Analysis of the distribution of ingested bacteria in nanoflagellates and estimates of grazing rates with flow cytometry. Aquat. Microb. Ecol. 21, $1-12$.

Buskey, E.J., 1997. Behavioural components of feeding selectivity of the heterotrophic dinoflagellate Protoperidinium pellucidum. Mar. Ecol. Prog. Ser. 153, 77-89.

Carlsson, P., Granéli, E., Olsson, P., 1990. Grazer elimination through poisoning: one of the mechanisms behind Chrysochromulina polylepis blooms? In: Granéli, E., Sundström, B., Edler, L., Anderson, D.M. (Eds.), Toxic Marine Phytoplankton. Elsevier, New York, pp. 116-122. 
Dahl, E., Lindahl, O., Paasche, E., Throndsen, J., 1989. The Chrysochromulina polylepis bloom in Scandinavian waters during spring 1988. In: Cosper, E.M., Bricelj, V.M., Carpenter, E.J. (Eds.), Novel Phytoplankton Blooms: Causes and Impacts of Recurrent Brown Tides and Other Unusual Blooms. Springer, Berlin, pp. 383-405.

Droop, M.R., 1959. Water soluble compounds in the nutrition of Oxyrrhis marina. J. Mar. Biol. Ass. UK 38, 605-620.

Edvardsen, B., 1993. Toxicity of Chrysochromulina species (Prymnesiophyceae) to the brine shrimp, Artemia salina. In: Smayda, T.J., Shimizu, Y. (Eds.), Toxic Phytoplankton Bloom in the Sea. Elsevier, Amsterdam, pp. 681-686.

Edvardsen, B., Medlin, L., 1998. Genetic analyses of authentic and alternate forms of Chrysochromulina polylepis (Haptophyta). Phycologia 37, 275-283.

Edvardsen, B., Paasche, E., 1992. Two motile stages of Chrysochromulina polylepis (Prymnesiophyceae): morphology, growth, and toxicity. J. Phycol. 28, 104-114.

Edvardsen, B., Paasche, E., 1998. Bloom dynamics and physiology of Prymnesium and Chrysochromulina. In: Anderson, D.M., Cembella, A.D., Hallegraeff, G.M. (Eds.), Physiological Ecology of Harmful Algae Blooms. Springer, Berlin (Heidelberg/New York), pp. 193-208.

Edvardsen, B., Vaulot, D., 1996. Ploidy analysis of the two motile forms of Chrysochromulina polylepis (Prymnesiophyceae). J. Phycol. 32, 94-102.

Edvardsen, B., Moy, F., Paasche, E., 1990. Hemolytic activity in extracts of Chrysochromulina polylepis grown at different levels of selenite and phosphate. In: Granéli, E., Sundström, B., Edler, L., Anderson, D.M. (Eds.), Toxic Marine Phytoplankton. Elsevier, New York, pp. 284-289.

Elbrächter, M., 1991. Faeces production by dinoflagellates and other small flagellates. Mar. Microb. Food Webs 5, 189-204.

Eppley, R.W., Holmes, R.W., Strickland, J.D.H., 1967. Sinking rates of marine phytoplankton measured with a fluorometer. J. Exp. Mar. Biol. Ecol. 1, 191-208.

Eschbach, E., Scharsack, J., John, U., Medlin, L.K., 2001. Improved erythrocyte lysis assay in microtitre plates for sensitive detection and efficient measurement of haemolytic compounds from ichthyotoxic algae. J. Appl. Toxicol. 21, 513519.

Frost, B.W., 1972. Effects of size and concentration of food particles on the feeding behaviour of the marine planktonic copepod Calanus pacificus. Limnol. Oceanogr. 17, 805-815.

Gjøsæter, J., Lekve, K., Stenseth, N.C., Leinaas, H.P., Christie, H., Dahl, E., Danielssen, D.S., Edvardsen, B., Olsgard, F., Oug, E., Paasche, E., 2000. A long-term perspective on the Chrysochromulina bloom on the Norwegian Skagerrak coast 1988: a catastrophe or an innocent incident? Mar. Ecol. Prog. Ser. 207, 201-218.

Granéli, E., Paasche, E., Maestrini, S.Y., 1993. Three years after the Chrysochromulina polylepis bloom in Scandinavian waters in 1988: some conclusions of recent research and monitoring. In: Smayda, T.J., Shimizu, Y. (Eds.), Toxic Phytoplankton Bloom in the Sea. Elsevier, Amsterdam, pp. 23-32.

Hansen, P.J., 1992. Prey size selection, feeding rates and growth dynamics of heterotrophic dinoflagellates with special emphasis on Gyrodinium spirale. Mar. Biol. 114, 327-334.
Hansen, B., Bjornsen, P.K., Hansen, P.J., 1994. The size ration between planktonic predators and their prey. Limnol. Oceanogr. 39, 395-403.

Hansen, F.C., Witte, H.J., Passarge, J., 1996. Grazing in the heterotrophic dinoflagellate Oxyrrhis marina: size selectivity and the preference for calcified Emiliania huxlyi cells. Aquat. Microb. Ecol. 10, 307-313.

Hauser, D.C.R., Levandowski, M., Hunter, S.H., Chunosoff, L., Hollwitz, J.S., 1975. Chemosensory responses by the heterotrophic dinoflagellate, Crypthecodinium cohnii. Microb. Ecol. 1, 246-254.

Heinbokel, J.F., 1978. Studies on the functional role of tintinnids in the southern California Bight. Part I. Grazing and growth rates in laboratory cultures. Mar. Biol. 47, 177-189.

Hewlett, P.S., Placklet, R.L., 1979. The probit and similar transformation. In: An Introduction to the Interpretation of Quantal Response in Biology. Edward Arnold Ltd., London, pp. 12-17.

Johansson, N., Granéli, E., 1999. Cell density, chemical composition and toxicity of Chrysochromulina polylepis (Haptophyta) in relation to different N:P supply ratios. Mar. Biol. 135, 209-217.

Johnsen, T.M., Lomsland, E.R., 1990. The culmination of the Chrysochromulina polylepis (Manton and Parke) bloom along the western coast of Norway. In: Granéli, E., Sundström, B., Edler, L., Anderson, D.M. (Eds.), Toxic Marine Phytoplankton. Elsevier, New York, pp. 177-182.

Jones, H.L.J., Leadbeater, B.S.C., Green, J.C., 1993. Mixotrophy in marine species of Chrysochromulina (Prymnesiophyceae): ingestion and digestion of a small green flagellate. J. Mar. Biol. Ass. UK 73, 283-296.

Kattner, G., Fricke, H.S.G., 1986. Simple gas-liquid chromatographic method for the simultaneous determination of fatty acids and alcohols in wax esters of marine organisms. J. Chromatogr. 361, 263-268.

Lessard, E.J., 1991. The trophic role of heterotrophic dinoflagellates in diverse marine environments. Mar. Microb. Food Webs 5, 49-58.

Li, A., Stoecker, D.K., Coats, D.W., Adam, E.J., 1996. Ingestion of fluorescently labelled and phycoerythrin-containing prey by mixotrophic dinoflagellates. Aquat. Microb. Ecol. 10, 139-147.

Maestrini, S.Y., Granéli, E., 1991. Environmental conditions and ecophysiological mechanisms which led to the 1988 Chrysochromulina polylepis bloom: an hypothesis. Oceanol. Acta 14, 397-413.

Manton, I., Parke, M., 1962. Preliminary observations on scales and their mode of origin in Chrysochromulina polylepis sp. nov. J. Mar. Biol. Ass. UK 42.

Meldahl, A.S., Edvardsen, B., Fonnum, F., 1994. Toxicity of four potentially ichthyotoxic marine phytoflagellates determined by four different test methods. J. Toxicol. Environ. Health 42, 289-301.

Myklestad, M.M., Ramlo, B., Hestmann, S., 1995. Demonstration of strong interaction between the flagellate Chrysochromulina polylepis (Prymnesiophyceae) and a marine diatom. In: Lassus, P., Arzul, G., Gentien, P., Marcaillou, C. (Eds.), Harmful Marine Algal Blooms. Intercept Ltd., Lavoisier, pp. 633-638. 
Nielsen, T.G., Kiorboe, T., Bjornsen, P.K., 1990. Effects of a Chrysochromulina polylepis subsurface bloom on the planktonic community. Mar. Ecol. Prog. Ser. 62, 21-35.

Nöthig, E.-M., Bodungen, B.V., 1989. Occurence and vertical flux of faecal pellets of probably protozoan origin in the southeastern Weddel Sea (Antartica). Mar. Ecol. Progr. Ser. 56, 281-289.

Nygaard, K., Tobiesen, A., 1993. Bacterivory in algae: a survival strategy during nutrient limitation. Limnol. Oceanogr. 38, 273279.

Olsen, R.E., Henderson, R.J., 1989. The rapid analysis of neutral and polar marine lipids using double-development HPTLC and scanning densitometry. J. Exp. Mar. Biol. Ecol. 129, 189-197.

Paasche, E., Edvardsen, B., Eikrem, W., 1990. A possible alternate stage in the life cycle of Chrysochromulina polylepis Manton et Parke (Prymnesiophyceae). Nova Hedwigia Beih. 100, 91-99.

Riegman, R., de Boer, M., de Senerpont Domis, L., 1996. Growth of harmful marine algae in multispecies cultures. J. Plankton Res. 18, 1851-1866.

Rosenberg, R., Lindahl, O., Blanck, H., 1988. Silent spring in the sea. Ambio 17, 289-290.

Schmidt, L.E., Hansen, P.J., 2001. Allelopathy in the prymnesiophyte Chrysochromulina polylepis: effect of cell concentration, growth phase and pH. Mar. Ecol. Prog. Ser. 216, 67-81.

Simonsen, S., Moestrup, O., 1997. Toxicity tests in eight species of Chrysochromulina (Haptophyta). Can. J. Bot. 75, 129-136.

Smayda, T.J., 1997. Harmful algal blooms: their ecophysiology and general relevance to phytoplankton blooms in the sea. Limnol. Oceanogr. 42, 1137-1153.

Spero, H.J., 1985. Chemosensory capabilities in the phagotrophic dinoflagellate Gymnodinium fungiforme. J. Phycol. 21, 181184.

Stabell, O.B., Pedersen, K., Aune, T., 1993. Detection and separation of toxins accumulated by mussels during the 1988 bloom of Chrysochromulina polylepis in Norwegian coastal waters. Marine Environ. Res. 36, 185-196.

Stoecker, D.K., 1984. Particle production by planktonic ciliates. Limnol. Oceanogr. 29, 930-940.

Strom, S.L., Benner, R., Ziegler, S., Dagg, M.J., 1997. Planktonic grazers are a potentially important source of marine dissolved organic carbon. Limnol. Oceanogr. 42, 1364-1374.

Tarran, G., 1991, Aspects of the Grazing Behaviour of the Marine Dinoflagellate Oxyrrhis marina, Dujardin. University of Southampton, Southampton, p. 188.

Teegarden, G.J., 1999. Copepod grazing selection and particle discrimination on the basis of PSP toxin content. Mar. Ecol. Prog. Ser. 181, 163-176.

Tillmann, U., John, U., 2002. Toxic effects of Alexandrium spp. on heterotrophic dinoflagellates: an allelochemical defence mechanism independent of PSP toxins. Mar. Ecol. Prog. Ser. 230, 47-58.

Tillmann, U., Reckermann, M., 2002. Dinoflagellate grazing on the raphidophyte Fibrocapsa japonica. Aquat. Microb. Ecol. 26, 247-257.

Tobiesen, A., 1991. Growth rates of Heterophrys marina (Heliozoa) on Chrysochromulina polylepis (Prymnesiophyceae). Ophelia 33, 205-212.

Underdahl, B., Skulberg, O.M., Dahl, E., Aune, T., 1989. Disastrous bloom of Chrysochromulina polylepis (Prymnesiophyceae) in Norwegian coastal waters 1988: mortality in marine biota. Ambio 18, 265-270.

Yasumoto, T., Seino, N., Murakami, Y., Murata, M., 1987. Toxins produced by benthic dinoflagellates. Biol. Bull. 172, 128-131.

Yasumoto, T., Underdahl, B., Aune, T., Hormazabal, V., Skulberg, O.M., 1990. Screening for hemolytic activity and ichtyotoxic components of Chrysochromulina polylepis and Gyrodinium aureolum from Norwegian coastal waters. In: Granéli, E., Sundström, B., Edler, L., Anderson, D.M. (Eds.), Toxic Marine Phytoplankton. Elsevier, New York, pp. 436-440. 